Discourse and Communication for Sustainable Education, vol. 11, no. 2, pp. 85-105, 2020

\title{
Evaluation of Enriched Learning Environment in the Context of Mathematical Reasoning from the Perspective of the Students and their Teacher
}

\author{
Tamer Kutluca \\ Dicle University, Turkey \\ Ali Tum \\ Ministry of National Education, Turkey \\ Ali İhsan Mut \\ Dicle University, Turkey
}

\begin{abstract}
The purpose of the current study is to investigate the learning process, which is enriched by using various teaching methods in the context of mathematical reasoning from the perspectives of seventh grade students and their mathematics teacher. In order to have an in-depth study, a qualitative research approach was preferred. This research was conducted with 23 seventh grade students and their mathematics teacher at a randomly selected public secondary school. Qualitative data was collected by using a semi-structured interview form developed for both the teacher and the students. As a result of this research, it was determined that this learning environment increased students' participation in the lessons, provided effective and permanent learning and encouraged the use of mathematical reasoning skills. In addition, it was found that this learning environment, which uses various learning ways, develops a positive attitude towards the lessons. Besides, according to the findings of this study, it was found that the learning environment in which various learning ways were utilized provided sufficient knowledge of concept and method to the students, and improved their mathematical reasoning skills.
\end{abstract}

Key words: enriched learning, mathematical reasoning, learning environment, sustainability.

\section{Introduction}

Teachers who take part in education that encourages the individuals to meet the needs of the society should make the necessary arrangements for the teaching of mathematics, which has an indispensable place in all areas of our lives. As a matter of fact, continuously changing living conditions require individuals who meet society needs such as creative thinking, being productive, making accurate decisions and problem solving (Ministry of National Education [MoNE], 2015; National Council of Teachers of Mathematics [NCTM], 1989; Salite et al., 2020). In fact, it is obvious that people 
frequently engage in activities involving numerical operations in their daily life and use these calculations intensively in establishing cause-effect relationships. It can be deduced that the individuals in this profile required by today's conditions indicate that their thinking and reasoning skills need to be well developed. Erdem (2015) states that mathematics, which is the most important tool that develops and uses this thinking and reasoning skills is the most important part of education. As in the past, today people accept mathematics as an auxiliary tool that meets their needs by making their lives easier. Since people can gain some skills such as mathematical thinking, effective problem solving, reasoning in logic and relating with daily life in addition to having basic mathematical concepts by means of doing mathematical activities, people have never been far from this vital tool in the historical process from past to present (MoNE, 2015; 2018a). In order for students to use these skills effectively, it is necessary to combine school mathematics and daily life mathematics in learning environments (Algani \& Eshan, 2019; Erdem, Gürbüz, \& Duran, 2011; Topuz \& Birgin, 2020). As Heasly et al. (2020) and Salite (2008) asserts that a circular causality between actors and environment characterized by the complex interconnected mechanisms in educational processes.

Curriculums for the mathematics course are created considering individual differences (MoNE, 2018a) because of the fact that learning can be provided in an easier, more effective and permanent way in the learning environment that is structured by considering the individual characteristics of the students. Indeed, it has been revealed in the related literature that considering individual differences is necessary and important in education and teaching (Erdem, Firat, \& Gürbüz, 2019). Learning environments in which teaching methods and approaches are utilized should be developed to encourage students to think, to reveal their mental processes, and to enable the individuals to realize their own learning (Erdem, 2015). It can be said that learning can be completely realized with these approaches. Therefore, the learning environments to be designed should not ignore individual differences and the students should be in the center of the learning process in this learning environment. As stated in the mathematics curriculum, teaching approaches that will make it easier for students to express their thoughts and judgments during the learning and problem-solving process should be preferred (MoNE, 2015; 2018a). By means of such approaches that take the student to the center, the knowledge of the student about the concepts or achievements that are aimed to be acquired is not just information. In other words, as a result of being able to establish a cause-effect relationship, a student can internalize the knowledge. For this reason, the activities to be used in learning environments should be structured in such a way that a student might be able to discover the knowledge rather than memorize (Novak \& Gowin, 1984). In addition, utilizing different approaches in learning environments helps students to get rid of their possible prejudices and motivate students in the concepts considered as difficult by them (Erdem, 2015). Since students' learning experiences, approaches and learning styles are different, sharing these differences in the classroom provides different perspectives to the students' learning processes, thereby enriching the learning environment. In this way, students can learn more meaningfully and effectively by influencing each other and; hence, they could have a chance to develop different ways of thinking and solution for the problems they will face (Özgen \& Alkan, 2014). As a matter of fact, it is inevitable that many learning activities take place together to teach a mathematical concept (Özgen \& Alkan, 2014). It should be considered that teaching concepts with various teaching methods and techniques can provide the student different perspectives, and this may be an alternative solution for the students who have difficulties in understanding some mathematical concepts and topics. For this reason, 
enriching the learning environment and activating students' many sensory organs and taking the students to the center of the learning activities are considered important in terms of effective learning.

When the reform studies on mathematics education and teaching (MoNE, 2015; 2018a; NCTM, 1989) and some related research (Erdem, 2015; Kramarski, Mevarech, \& Lieberman, 2001; Polaki, 2002) are examined, it can be understood that mathematical reasoning skill has an important role in mathematics learning process. As a matter of fact, it can be said that the effect of mathematical reasoning may be extensive in the process of learning mathematics due to the existence of skills such as thinking, research and questioning arising from the nature of mathematics (Polaki, 2002). It is stated that there is a relationship between learning mathematics and mathematical success with reasoning skills, and that students who have better reasoning develop effective solutions by developing different perspectives on the problems (Kramarski et al., 2001). In addition, one of the main purposes of teaching mathematics in schools is to make studies on mathematical reasoning skills through the acquisition of mathematical skills in order to overcome the problems that students may encounter in their daily lives (MoNE, 2018a). As a matter of fact, in the student performance evaluation report for the High School Entrance Exam (LGS) held in the 2017-2018 academic year, it was determined that the course with the lowest correct answer rate and the highest rate of dropout was mathematics (MoNE, 2018b). In fact, it was determined that the subject with the lowest correct answer rate and the highest rate of none-answered items was mathematics according to the student performance evaluation report for the High School Entrance Exam (LGS) held in the 2017-2018 academic year. Indeed, when the questions asked in LGS in recent years are examined, it is seen that the students should have adequate rate of reasoning skills to solve these items.

Much of the research focused on the use of educational games to teach mathematics (Gök, 2020). There are also studies investigating the effect of teaching approaches which includes setting up the relation between the concepts and daily life (Algani \& Eshan, 2019; Erdem et al., 2011). Besides, the research in which technology assisted teaching is devised has also been studied (Polaki, 2002; Topuz \& Birgin, 2020). In related literature, there are research about the improvement of mathematical reasoning in learning environment involving teaching approach based on discussion (Pape, Bell, \& Yetkin, 2003). In addition, there is research on educational games in mathematics teaching (Gök, 2020), computer supported teaching activities (Kramarski \& Zeichner, 2001), meta-cognitive strategies in teaching (Kramarski \& Zoldan, 2008), teaching approach including activities based on prediction (Kasmer \& Kim, 2011). However, in Turkey, there is a dearth of research based on the metacognitive strategies approach for the development of mathematical reasoning (Kramarski \& Zoldan, 2008), and enriched learning environment including many teaching methods (Erdem, 2015; Erdem et al., 2019). Moreover, there were only a limited number of studies in which learning environments were designed, and the effectiveness of these methods was not probed sufficiently. Therefore, it is necessary to examine enriched learning environments in the context of mathematical reasoning in terms of contributing to both the literature and the curriculum to be applied and the mathematics teachers who will teach. The aim of this study is to evaluate the learning process in the context of mathematical reasoning from the perspectives of the seventhgrade students and their mathematics teacher conducting their mathematics lessons in the learning environment enriched with different teaching methods. 


\section{Research Methods}

\section{Design of the Research}

In this research, a qualitative research approach, which presents the opportunity to work in detail with few people, was preferred. Since the aim was to reach reasonable and reliable conclusions from the experiences and views of the teachers and students in the learning process, the phenomenological design was utilized in this study. In this study, the descriptive approach of this design was used as the basis, since the participants' experiences and opinions about the process were examined in depth. Describing the experiences of the participants related to the process or the phenomenon rather than what they know is essential for descriptive phenomenological studies (Merriam, 2009).

\section{Research Participants}

Random sampling, criterion sampling and maximum variation sampling methods were used in the study. This research was conducted with 23 seventh grade students and their mathematics teacher at a randomly selected public secondary school, which is at the center of a province in Southeast Anatolia Region in Turkey. The seventh-grade students who were the participants of the study were at the intermediate level according to the first semester school report card. In addition, according to the learning styles scale, the class to be included in the study group was chosen according to the best heterogeneous characteristics in terms of learning preference styles.

Due to the fact that the seventh grade students have better adaptation to the middle school compared to the $5^{\text {th }}$ and $6^{\text {th }}$ grade students, these students had no worries about centralized exams for entrance to the secondary education schools as the $8^{\text {th }}$ grade students had, that the integers subject and the rational numbers and ratio subjects related to the fractions subject still continue at this grade level. Therefore, the study group was chosen from seventh grade students. In order to keep the identities of the students in the study group confidential, they were coded as S1, S2, S3... However, since there was only one mathematics teacher included in the research, he was coded as "Mathematics Teacher". In addition, student diaries were given directly, and were coded as S1d, S2d... The mathematics teacher in the study group has held an undergraduate level from a university and he has had 13-year professional mathematics teaching experience. The gender of the teacher was male. Descriptive statistics of seventh grade students in the study group are given in Table 1.

Table 1

Descriptive Information about Participants

\begin{tabular}{llcc}
\hline \multirow{2}{*}{ Gender } & & $\mathrm{f}$ & $\%$ \\
\cline { 2 - 4 } & Female & 10 & 43.5 \\
\cline { 2 - 4 } Learning Styles & Male & 13 & 56.5 \\
\cline { 2 - 4 } & Diverging & 6 & 26.1 \\
\cline { 2 - 4 } & Assimilating & 5 & 21.7 \\
\cline { 2 - 4 } & Converging & 5 & 21.7 \\
\cline { 2 - 4 } & Accomodating & 7 & 30.4 \\
\hline Total & & 23 & 100 \\
\hline
\end{tabular}




\section{Data Collection Tools}

In this study, data was collected by means of Learning Styles Scale (LSS), semistructured interview forms for teachers and students and student diaries for learning environment in the second semester of 2018-2019 academic year. It is important to use the diversity of data in order to achieve results from different perspectives by involving the participants with various characteristics in the research and revealing their different perceptions and experiences. Verification of the data collected by different methods and techniques such as interview and document analysis increases the validity and reliability of the results. In other words, supporting the findings of the interview with the documents increases the credibility of the research (Yıldırım \& Şimşek, 2016).

Learning Styles Scale (LSS). The scale developed by Kolb (2005) and adapted to the Turkish language by Gencel (2007) was used to determine the learning styles of the students. There are 12 items in the scale; each item has 4 alternatives for concrete experience (CE), reflective observation (RO), abstract conceptualization (AC), and active experimentation (AE) learning styles, so that they can be filled in the missing items. For the alternatives of each item, students were asked to score 4, 3, 2, 1 from the most appropriate alternative to the least suitable one. In this study, Cronbach Alpha reliability coefficients were calculated as 0.75 for $\mathrm{CE}, 0.68$ for $\mathrm{RO}, 0.71$ for $\mathrm{AC}$ and 0.75 for $\mathrm{AE}$.

Semi-Structured Interview for Teachers and Students. Items used in semi-structured interviews were prepared by reviewing the related literature, and interview forms were prepared by utilizing some of research such as Erdem (2015). In the interview form conducted with the mathematics teacher, questions as the following were asked from him:

"Does the designed learning environment help students to strengthen and develop their mathematical reasoning?"

"How does the designed learning environment affect students' learning?"

"What do you think about the teaching materials used in the designed learning environment?"

Besides, in the semi structured interviews, the students were asked the following questions:

"What do you think about the designed learning environment?"

"How did the designed learning environment contribute to you?"

"What are the differences between the applications in the current designed

learning environment and applications in your previous lessons?"

"Has the teaching performed in the designed learning environment made changes in the role of teacher and student? If yes, can you explain?"

According to the learning styles of diverging, assimilating, converging and accomodating, eight students in total, two students from each style were selected randomly, and semi-structured interviews were conducted with these participants. Semi-structured interviews were recorded by means of a voice recorder.

Students' Diaries Related to Learning Environment. After the teaching process that took place every week during the learning process, the students were given a diary form to jot down their thoughts or reflections about the learning environment. 


\section{Data Analysis}

The data obtained by administering LSS to students was analyzed by means of the Statistical Package for Social Sciences (SPSS 22) program. The scores of the components of the learning styles were calculated with the answers given to the LSS, which contains a total of 48 items, including 12 items (AC, CE, AE, RO) for the components of each learning style. After that, AC-CE and AE-RO combined scores were calculated. Learning styles were specified by determining intersection regions by placing "AC-CE" to " $\mathrm{y}$ " axis and AE-RO to " $\mathrm{x}$ " axis on the coordinate axis as specified by Kolb and Kolb (2005).

Interview voice recordings and student diaries were stored in computer environment. All qualitative data was analyzed by using the content analysis method. In this analysis; by grouping data according to similarities and differences, themes, categories and codes are created and parallel or related expressions are written under the same category (Yildirim \& Şimşek, 2016). In addition, some expressions about the code from the interviews and diaries were directly quoted without making any changes. The coding in the content analysis of the data were independently done by two researchers and two mathematics educators who are experts in their fields, who lecture courses such as Research Projects, Qualitative Data Analysis. The reliability formula of Miles and Huberman (1994) was used to ensure trustworthines of the study by calculating inter-rater reliability of coding when multiple researchers were involved in the process of coding. This formula is based on the ratio of aggrements to the sum of agreements plus disagreement. In this context, coding reliability in the study was calculated as $89 \%$. This means that the coding reliability was very high.

\section{Research Procedure}

As stated under the "participants" title, this research was conducted with 23 seventh grade students and their mathematics teacher at a randomly selected public secondary school, which is at the center of a province in Southeast Anatolia Region in Turkey in the spring semester of 2018-2019 academic year. Besides, according to the LSS, the class to be included in the study group was chosen according to the best heterogeneous characteristics in terms of learning preference styles.

In a total of 6 weeks (i.e. 26 lesson hours), the designed teaching program was implemented with these students. Whereas the sessions were 6 class hours in the third week, the sessions were 4 lesson hours in the other weeks. In accordance with the learning objectives on integers and fractions in the elementary and secondary school mathematics curriculum (MoNE, 2018a), the teaching was carried out by utilizing various techniques. These techniques were as follows "Technology supported activities, Educational games, Concrete materials, Cartoons, Discussion in heterogeneous cooperative groups, Setting up relation with daily life or real life". The activities implemented in the teaching are taken from the Tum and Kutluca (2019) study, which includes activity suggestions that can be used to develop mathematical reasoning skills. Some examples are given below for each technique used in the implementation process. For example; technology supported activities were designed by means of Geogebra dynamic mathematical software. These activities were named as "Identify, model and compare fractions", "Let's make sense of multiplying and dividing fractions", "Memo the Shark and Sweety Bird and Elevators of ASTUM Hospital", and "Bring Marsuplami to Her Family". 
Each activity was taught in collaborative groups with the active participation of the students under the guidance of the researcher on the smart board, and the students were required to engage with each of the activities.

\section{Finding and Discussion}

The qualitative data collected to determine the participants' views on the learning environment, the codes reached as a result of content analysis, and the covering categories and the theme are presented in Table 2 . The data was interpreted by means of presenting direct quotes related to each code.

Table 2

Frequency of Views Based on Theme, Categories and Codes

\begin{tabular}{|c|c|c|c|c|c|}
\hline Theme & $\begin{array}{l}1^{\text {st }} \text { degree } \\
\text { category }\end{array}$ & $\begin{array}{l}2^{\text {nd }} \text { degree } \\
\text { category }\end{array}$ & $\begin{array}{l}3^{\text {rd }} \text { degree } \\
\text { category }\end{array}$ & Code & $\mathrm{f}$ \\
\hline \multirow{13}{*}{ 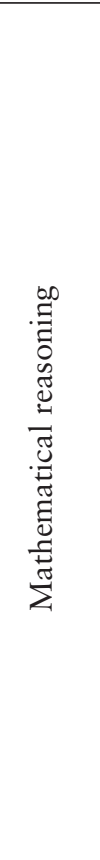 } & \multirow{13}{*}{ 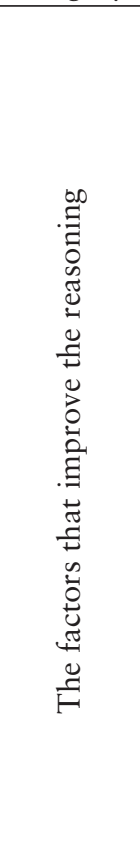 } & \multirow{3}{*}{ 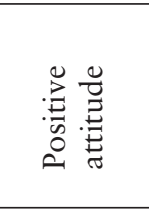 } & \multirow{3}{*}{$\begin{array}{l}\text { Increasing } \\
\text { participation }\end{array}$} & $\begin{array}{l}\text { Making the teaching } \\
\text { funny* }\end{array}$ & 23 \\
\hline & & & & $\begin{array}{c}\text { Considering individual } \\
\text { differences }\end{array}$ & 12 \\
\hline & & & & Rewarding & 8 \\
\hline & & \multirow{10}{*}{ 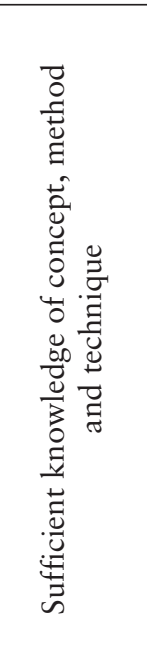 } & \multirow{6}{*}{$\begin{array}{c}\text { Efficient and } \\
\text { permanent learning }\end{array}$} & Visualisation & 15 \\
\hline & & & & Concretization & 19 \\
\hline & & & & $\begin{array}{l}\text { The use of various teaching } \\
\text { methods and tecniques }\end{array}$ & 23 \\
\hline & & & & $\begin{array}{c}\text { Creating a discussion } \\
\text { environment }\end{array}$ & 13 \\
\hline & & & & $\begin{array}{l}\text { Giving effective hints } \\
\text { and feedbacks }\end{array}$ & 12 \\
\hline & & & & Relating with daily life & 13 \\
\hline & & & \multirow{4}{*}{$\begin{array}{l}\text { Encouraging the use } \\
\text { of reasoning }\end{array}$} & Allow explanation & 9 \\
\hline & & & & $\begin{array}{l}\text { Solving in group by using } \\
\text { open ended problems }\end{array}$ & 11 \\
\hline & & & & $\begin{array}{c}\text { Establishing the cause and } \\
\text { effect relationship }\end{array}$ & 9 \\
\hline & & & & $\begin{array}{c}\text { Encouraging the use of } \\
\text { various solution strategies }\end{array}$ & 8 \\
\hline
\end{tabular}

* By means of Educational Games, Cartoons, Technology Supported Activities and Concrete Materials.

** Since one participant expresses opinions about more than one code, the sum of the frequency for the codes is more than the number of participants.

\section{Increasing Participation}

Under this category, three codes were reached. These are namely "making teaching fun", "considering individual differences" and "rewarding”. Sample views on each code are included and then interpretations were made. 


\section{Making the Teaching Enjoyable}

Teacher and students stated that the teaching process became funny with the use of various teaching methods in the learning environment and; thus, increased participation in the lesson. In this regard, direct expressions were given from both teacher and student interviews and student diaries that different teaching methods are used in these learning environments and this provides a more enjoyable environment for the students.

Mathematics Teacher: "... At first I was not sure that an activity that seemed so much game could really give the subject to the students. However, after the activities, I realizaed that this was really logical and that the students participated in the process with pleasure like never before. There was a huge difference between students' participations in the form of question and answer, or when we teach the topic, then solved an example question, and expected them to solve the question, and when we did it with activities and materials. When we looked at it from this perspective, I found it really effective and useful..."

S1d: "... Various activities on the smart board, solving questions, playing games and so on were very nice. We solved different problems and easy problems with our friends. It was more enjoyable when there was activity in the lesson..."

Since the interview data and the data from the participants' diaries support each other, it can be said that the participation in the course increased because the various teaching methods used in the learning environment made the process fun.

\section{Considering Individual Differences}

Teachers and students indicated that individual differences positively affected the participation in the learning environment when these differences were considered. Some of the expressions from the interviews and participants' diaries indicating individual differences in the learning environment were taken into account and that this had positive reflections in the course participation are given directly below.

S12d: "... I think it is very nice that this course is designed so that we can study as a team. Because doing things on your own individually is both boring and more difficult."

S13: "...In the past, we often did not participate in the discussions in the mathematics lessons. However, in the new learning environment, the teacher behaved everyone well regardless of the lazy or hardworking student. Therefore, everyone wanted to participate in the mathematics lessons. The teacher explained the points that my classmates did not understand in math lesson... Thanks to this attitude, everyone participates in the class..."

It can be said that the interview and the diary data are consistent with each other and taking the students' individual differences into consideration in this learning environment increases the participation in Math classes. 


\section{Rewarding}

Teachers and students stated that using rewarding mechanism in this learning environment increases participation. In this regard, sample excerpts from the interview and students' diaries about rewarding in the learning process in this learning environment and that it has a positive effect on class participation are given below.

Mathematics teacher: "... You were giving gifts to the winning groups in the games. This made other students even more ambitious and they were more focused on the lessons. ..."

S20: "...For example, when he says I will give a reward to the group that can solve this question, everyone starts to raise their fingers... When he heard about the award, he was both motivated, participated, and he learned because be participated in...."

S6: "... When we answer correctly and in games, the teacher gives us a reward. Thus, everyone becomes a competitor against each other. Everyone raises their fingers to participate in the lesson...."

The interview and student diaries verify each other, and we can say that rewarding in the learning environment increases students' participation.

\section{Efficient and Permanent Learning}

Under this category, 6 codes were identified. These are namely: "Visualization", "Concretization", "Using Various Teaching Methods and Techniques", "Creating a Discussion Environment", "Effective Hints and Feedback" and "Relating with Daily Life". By giving some excerpts from the interviews and students' diaries related to each code, there were some interpretations presented.

\section{Visualisation}

The participants stated that the learning environment in which the teaching was carried out came to the fore visually and this provides effective and permanent learning. In this regard, the excerpts from the interviews and the statements from the student diaries, which show that visual elements are included in this learning environment and that they have positive reflections on students' learning, are given below.

Mathematics Teacher: "...In this learning environment, the concepts and the learning objectives, whether in the paper-pencil environment or on the smart board, were taught visually using real life situations with the pictures and cartoons. Since the students could understand the concepts better by means of visual manner, the activities and the applications made on the smart board were designed with visual support. I think that the visualization of the concepts to be taught will make it easier for students to learn and that this information will remain in students' minds for longer..."

It can be said that interviews and student diaries verify each other, visual materials are included in this learning environment and this provides effective and permanent learning for the student. 


\section{Concretization}

It was stated by teachers and students that the concretization carried out in this learning environment positively effects students' learning and provides permanent learning. In this regard, statements from the interviews and student diaries about the concepts and subjects taught in concrete ways in this learning environment are given below.

Mathematics Teacher: "...You brought the fraction abacus, which is made of colored foam-shaped cylinders. It attracted the attention of students and me. By means of this abacus, students concretely saw the relation between a fraction and the whole, the fact that the fractions consisted of unit fractions, and the number of the unit fractions in a fraction, the conversion between improper fractions and mixed numbers. Students could also see more concretely in the activities that you prepare on the smart board. For example, a student models his own fractions with instructions and makes comparisons, draws some conclusions and discovers intended knowledge himself. In the fraction abacus you have prepared, the student will be able to see the fractions effectively and learn the concept of the fraction since the student is active in the learning process by placing and touching the elements of the abacus."

S22: "... The way to understand the lesson more effectively is to use fraction abacus and concept map. In the abacus materials, we learned the concepts of equivalent fractions and unit fraction in the fractions subjects, and we learned the ordering the fractions by means of the wheel of the fortune. We learned the topics in a funny way in the form of games. We learned how to add, subtract, multiply and divide fractions for the problems in our lives with smart board applications by doing activities both visually and concretely..."

When the interview and student diaries are examined, it can be said that these two data source verify each other, and it can be seen that the designed learning environment enhances the permanent and effective learning since the mentioned learning environment embodies the learning.

\section{The Use of Various Teaching Methods and Techniques}

It is stated by the participant teacher and the students that utilizing various teaching methods and techniques in this learning environment will provide effective and permanent learning by improving different perspectives in terms of the students. In this regard, some of the excerpts of interview and student diaries about various methods and approaches are used in this learning environment and these have positive reflections on learning are given below.

Mathematics Teacher: "...In this environment, students were taught the topics of integers and fractions with various teaching methods such as activities on the smart board, games, materials, cartoons etc. This will enable the student to gain different perspectives. Besides, this will enable the student to think about the concepts, topics or problems in various ways..." 
S7d: “... We learned positive (+) and negative (-) numbers, which are integers. We examined the shark Memo and the cute bird being under the sea or in the air. When the cute bird went up one stage, Memo the Shark dove down one stagen and we could learn the concepts of both positive and negative. We learned what the concepts of positive and negative with cartoon and worksheets are...."

When we examine the interview and student diaries, it is possible to see that these data verify each other. In this learning environment, it can be said that the students' learning to be permanent and effective has increased due to the use of different learning methods in this environment.

\section{Creating a Discussion Environment}

It was stated by the participant mathematics teacher the students that students are active in the lessons and support each other's learning thanks to the discussions between heterogeneous groups in the learning environment. In this regard, the sample interview excerpts and statements from the students' diaries about the discussion environment created in this learning environment and this would have positive reflections on learning are given below.

Mathematics Teacher: "...You did not randomly create groups. Instead, you determined how they preferred to learn by applying a test to students and placed different students in groups, taking into account both test results and the students' math grades. This not only led to the emergence of different ideas in the discussions but also enabled passive students to learn from other students..."

S12: “... We were solving all our questions by discussing as a group. As a result of our discussion, we had more knowledge than the others by means of sharing our knowledge... While our teacher was telling about the cartoons from the smart board, we were listening and discussing them in our group..."

When the interview and students diaries data are examined, it is understood that these data support each other. In other words, teachers and students agree that in this learning environment, group discussions can be realized and that this provides a better learning. It can be said that the learning of students is more effective and permanent in this learning environment because of the supplying a discussion environment.

\section{Giving Effective Feedbacks}

Teachers and students stated that in the learning environment the researcher helped the students to correct their mistakes that they made and to understand the points that they did not understand by giving effective hints and feedbacks. The expressions from the interviews and students' diaries that can be accepted as an example in this regard are given below.

Mathematics Teacher: "... While the students were solving problems, asking them how they think and why they do this solution will contribute to the 
development of their reasoning. Because students tried to justify what they did by dealing with problems more and pushing their minds. At the same time, the students were able to recognize their mistakes and correct these mistakes. Students had difficulty in solving some problems while solving these problems in-group. You got involved in the points or situations where they had difficulties. You helped students find the solution by asking some questions and giving hints... When necessary, you explained some issues to them with various examples when they stuck or could not understand while solving problems. In other words, you were guiding them by giving clues to reach the accurate solutions..."

Both of the data from the interviews and students diaries verify each other in that, "in this learning environment, both of the teacher and the students agree that the teacher (the researcher) helps students learn effectively and comprehend the topics by providing hints and feedbacks on problem solutions". Therefore, it can be said that the students could have a chance of more effective and permanent learning thanks to having been given effective hints and feedbacks in this learning environment.

\section{Relating with Daily Life}

The teacher and students stated that the concepts were taught by associating the concepts with daily life in the learning environment, and because this way of teaching was more familiar to the student, it attracted them to the lesson and more effective learning took place. Some of the parts from the interviews and students' diaries indicating that this aspect of the teaching environment provided positive reflections on learning are given below.

Mathematics Teacher: "...I think the teaching materials used in this study have a potential to increase permanent learning. Cartoons, worksheets, smart board applications and solved problems will always attract students to the lesson and make it easier for them to learn, as they are created from real-life sections. To illustrate, since the activities "escalators in cartoons", "the elevator activity on the worksheet," and "sharks with birds" are chosen from daily life, I think it is more effective in making sense of positive and negative integer concepts in terms of the students..."

S6: “... Our learning in different ways allowed us to understand better. When subjects, examples, problems and activitites are selected from daily life as much as possible, they would be more permanent in our memories. Especially cartoons attract our attention..."

When the interview and students' diaries data was examined, it can be understood that these data sources confirm each other. According to these data, the teacher and the participant students stated that the students learned the concepts and subjects more effectively and permanently because of the fact that teaching in this learning environment was associated with daily life. In the light of this finding, it can be said that teaching the students by associating the concepts or subjects with daily life in a learning environment makes learning more effective and permanent. 


\section{Allowing Explanation}

The teacher and participant students stated that enabling students to share their thoughts in the learning environment, and behaving in this manner would allow the students to use their mathematical reasoning skills as well contribute to the mathematical reasoning skills of the students. In this regard, some parts of interviews and students' diaries codes were given in the following paragraphs.

Teacher: "In this teaching process; enabling students to share their ideas in worksheets, cartoons or discussions within groups, and asking them why they think this solution, especially when solving problems, will contribute to the development of their reasoning. Because the students tried to justify what they were engaging and doing with the problems more and more by pushing their minds. At the same time, students were able to recognize and correct this when they had mistakes... In this way of learning, students were able to choose to express their thoughts more easily. When the teacher asked questions to the students in the classroom or when the teacher expected any answers from them, the students were afraid to make mistakes. Due to the fear of answering wrongly, there was a situation of not participating to the class discussions. With supporting group activities by means of activities and games, everyone began to respond in a way that was what they thought whether it is logical or illogical, right or wrong. And indeed, this situation results in different results and different approaches."

S12d: "... In these lessons, the teacher was asking questions like "why do you think so?", "Why?", "How?” etc. For example, when I was at front of the wheel of the game "the wheel of fortune", he asked what I was aiming for before turning the wheel, why, whether the fraction score that came after the wheel was good or bad for our group, and why. We had to think to reply such questions. However, I can say that this was beneficial in terms of us. It allowed us to interpret what we did and say what we thought..."

When the interview and students' diaries data werere examined, it was found that these two data sources support each other. According to these data, in this learning environment, mathematics teachers and participant students stated that creating an environment in which students can express their thoughts easily, giving students opportunities to explain and encouraging them to use their mathematical reasoning contributes to the development of this skill. Therefore; in the light of this finding, it can be said that enabling students to explain themselves in the learning environment contributes to their mathematical reasoning skills.

\section{Using Open-Ended Problems}

Teachers and students stated that utilizing open-ended problems that require reasoning in the learning environment and solving these types of problems in a group triggers or stimulates students' mathematical reasoning skills and contributes to the development of this skill. The statements from the interviews and students' diaries reflecting this picture are given in the following quotations. 
Mathematics Teacher: "In this learning environment, you used open-ended problems instead of multiple-choice items. In my opinion, these problems enhances students' reasoning skills. Because, in multiple-choice items, students focus merely on the alternatives and try to solve the problems according to these alternatives. However, in open-ended questions, the student should understand the problem and explain what is asked and given in the problem in detail. There is an idiom as, "Understanding the problem is half of the solution". Just like what is meant in this idiom. To achieve the "required result or solution" by means of utilizing the "given", a student should plan how to solve the problem by using logic. In addition, students' solving openended problems as a group will make passive students more active. In addition, since they solved the problems in-group, each student contributed to others's thinking by sharing his or her own opinion. Sometimes a student may not think what the other one is thinking. In one sense, they solve problems by combining their knowledge and reasoning."

It can be seen that interview and students' diaries verify each other data if these data sources are considered. Therefore; according to these data sources, it can be said that solving open-ended problems in-group in this learning environment will encourage the students to use mathematical reasoning skills and thus contribute to the development of this skill.

\section{Establishing the Cause and Effect Relationship}

The teacher and the participant students stated that utilizing a teaching approach to establish cause and effect relation in teaching in this learning environment contributed to the development of students' mathematical reasoning skills. The statements from the interviews and students' diaries reflecting this aspect of the current study are presented in the following statements.

Mathematics Teacher: "In general, as a mathematics teacher, we do not consider mathematical reasoning, logical thinking or interpretation. We teach the topics and then immediately solve questions on the board, and we expect the students to solve them immediately. Actually, this way of our teaching is in a memorization format. However, our mathematics curriculum was not based on this idea. Unfortunately, this is a problem of our country. In this learning environment, you tried to present the logic or underlying reason of the concepts and problems rather than memorization. In every point of the lessons, for what the participants did or said, you asked thems some questions like "why so?", "what is the reason for this?" in order to establish a cause and effect relationship instead of memorizing the related cases. To illustrate; frankly, I had question marks in my head about the wheel of the fortune game, when I first thought that they would just turn the wheel and then get the points. In the process of the time; however, I saw that you made students make comments about the fractions on the wheel and justify their solutions by means of asking students questions like, "What are you aiming for?", "Why is it?", "What do you think about the score?", "Is it good for you?" before and after turning the wheel. Likewise, in the treasure hunter game, 
students should consider and decide on their own actions according to their positions in the game."

When the interview and students' diaries data were examined, it can be understood that these data sources confirm each other. According to these data, teaching in the designed learning environment in the form of cause and effect relationship encourages students to use their mathematical reasoning and contributes to the development of these skills.

\section{The Use of Various Solution Strategies}

The teacher and the students stated that encouraging students to use various solution strategies in problem solving in this learning environment contributes to students gaining different perspectives and discovering their own solutions. In addition, it was stated by the teacher and participant students that this contribution would force students to use their reasoning skills. The excerpts from the interviews and parts of students' diaries reflecting this side of the present study are given as follows.

Teacher: "Integers and fractions are taught by means of different teaching methods. This will enable the student to gain various perspectives. It will enable the student to think about the concepts or problems in various ways because a problem will have multiple solution ways. No students may want to solve a problem in a certain ways or the same way or some of them may have different thoughts...You solved the problems for the students in detail by using different solution methods. We, mathematics teachers, do not do this most of the time. More precisely, we show the solution directly and pass it. However, in this way, the students themselves learnt to reach the solution. Discovering created a new feeling for them."

S17d: "... While we were solving problems by the group, we were sharing what we thought with each other, and solving problems in different ways, but the result was the same..."

When the authors examined the interview and student diaries, it is possible to see that these data verify each other in the context of the code of "encouraging the use of various solution strategies". Therefore in this learning environment, it can be said that approaching students in a way that encourages the use of different solution strategies in problem solutions will both encourage students to gain different perspectives and to use their reasoning skills by discovering their own solutions. In summary; considering all the findings, it can be said that due to the utilization of various teaching methods in the learning environment, "Making the teaching enjoyable", "Considering individual differences" and "Rewarding" increases "students' participation to the lessons", and this yields a "positive attitude" towards both to the lessons and the problems. In addition, it can be said that the features of this learning environment as "Visualization, Concretization, Using various teaching methods and techniques, Creating discussion environments, giving students effective hints and feedbacks, and Relating concepts with daily life" make "Students' learning effective and permanent".

At the same time, since this learning environment "allows students to explain", "to solve open-ended problems as a group", "to establish a cause-and-effect relationship", 
and "to encourage the use of various solution strategies in problem solutions", it can be said that "it encourages students to apply to their mathematical reasoning". It can be said that the students have obtained "sufficient concept and method knowledge" since this learning environment provides both "effective and permanent learning" and "encourages the utilization of reasoning skills". In the light of all of these findings, it can be said that this learning environment creates positive attitudes in terms of students, provides sufficient concept and method knowledge, and that the student develops mathematical reasoning skills.

\section{Conclusions}

The aim of this research is to evaluate the learning process in the context of mathematical reasoning from the perspectives of the seventh-grade students and their mathematics teacher conducting their mathematics lessons in the learning environment enriched with different teaching methods. In the analysis of the interviews and students' diaries regarding the learning process carried out, the results for the codes included in the categories as "increasing students' participation", "Providing Efficient and Permanent Learning" and "Encouraging the Use of Reasoning Skills" were determined in a specific framework. Moreover, in the general framework, the results regarding the mathematical reasoning skill theme, which covers the categories of "Positive Attitude" and "Sufficient Knowledge of Concept, Method and Technique", have been revealed. Considering all of the findings, it can be concluded that "making the teaching process funny", "considering individual differences" and "rewarding" due to the utilization of various teaching methods in the learning environment "increases the students' participation in the lessons" and; in this way, the student creates a "positive attitude towards both the mathematics lessons and mathematics problems". The fact that the teaching process took place in a fun way by using various teaching methods enabled the students to enjoy the mathematics lessons and; thus, it can be said that the students participated more in the mathematics lessons. This result is in parallel with many studies stating that the teaching performed in this study makes the students active in the lessons and increases their participation in the lesson (Erdem, 2015).

It was determined that utilizing rewarding mechanism in the problem-solving activities and group game activities in the learning environment increased the participation of the students in the lessons. This result is compatible with the results of some researches, which indicate that the effective use of reinforcers affects learning positively (Dovis, Van der Oord, Wiers, \& Prins, 2013). It was determined that the teaching by considering the individual differences of the students increases the students' participants in the learning environment. With this result, it can be concluded that the participation in the lesson increases thanks to the regulation of the learning environment by considering the individual differences of the students. Since students have different characteristics such as learning styles, talent, intelligence, etc., it is accepted as important to consider these individual differences in mathematics teaching (Erdem et al., 2019). In this context, there can be found many studies reporting that learning environments where individual differences are taken into consideration increase students' achievement, provides interest and motivation toward the lesson and contributes to the formation of permanent learning (Özgen \& Alkan, 2014). 
In this learning environment, it can be said that the utilization of "visualization", "concretization", "various teaching methods", "creating a discussion medium", "giving students effective hints and feedback", and "relating the subjects with daily life" provide effective and permanent learning in terms of participant students. It was determined that visualization is at the forefront in the current enriched learning environment and this enabled both an enjoyable teaching-learning period and provided effective and permanent learning. Therefore, effective and permanent learning was provided by using different types of visual activities and materials such as the use of caricature and technology supported teaching applications in the learning environment. Many research studies emphasize that different types of visual stimuli are important for permanent learning in the learning environment (Çetin \& Mirasyedioğlu, 2019; Ertem-Akbaş, 2019).

The results of the study revealed that the concretization was achieved by using concrete materials, and technology supported applications in the designed learning environment and this provided enjoyable and permanent learning for the sake of the students. The conclusion that concrete materials and technology supported applications provide meaningful and permanent learning by providing concretization in the learning environment, and the importance of using these activities in teaching coincide with many studies in the literature $(\mathrm{Ok}, 2020)$. Moreover, effective and permanent learning takes place due to the use of various teaching methods, giving students different perspectives and involving students' learning preferences in a way that appeals to many sensory organs. This finding is parallel with the findings of some studies stating that learning environments in which students actively participate in different teaching methods that address students with different characteristics contribute positively and permanently to their learning (Erdem, 2015; NCTM, 1989; Özgen \& Alkan, 2014; Pape et al., 2003).

Creating a discussion environment among the heterogeneous groups organized for this designed learning environment revealed that learning takes place more effectively and permanently. Based on this result, it can be said that discussions within heterogeneous groups enable students to have a more active role in the learning process, and that students with different individual characteristics provide effective and permanent learning through gaining different perspectives in learning. Therefore, students interact, act actively and learn from each other in the discussions in these heterogeneous groups. Many studies in the literature support this result (Erdem, 2015; Pape et al., 2003). It was determined that giving effective hints and feedback to students in the learning environment allows students to correct them by realizing their own mistakes, and that some incomprehensible issues help them learn more effectively. Moreover, participants solved the problems more effectively and achieved the learning objectives more efficiently by means of the hints and feedbacks given to the students. In the designed learning environment, teaching by setting relations with daily life showed that the concepts or subjects to be taught are learned more effectively. Based on this result, it can be said that the structuring of teaching in a way that is related with daily life provides more effective and permanent learning. In the literature, it is possible to find many studies supporting this result (Çetin \& Mirasyedioğlu, 2019; Erdem et al., 2011).

This learning environment encourages students to use reasoning skills because of its features such as enabling students to explain, solving open-ended problems as a group, preferring an approach to establish cause and effect relationship, and encouraging the use of different solution strategies in problem solutions. It was determined that adopting 
an approach that enables students to share their thoughts in the designed learning environment has a positive effect on students' use of mathematical reasoning skills and the development of this skill. Based on this result, it can be concluded that giving students opportunities to explain their thoughts or mathematical activities enables them to use mathematical reasoning skills and contribute to the development of this skill. Erdem (2015) states that it is important for students to ask their teachers or friends about the points that they have difficulties or cannot understand, in order to grasp the subject completely. Enabling students to ask questions about the subject and express their thoughts in problem solving or class discussions will enable them to see and correct their own mistakes using their judgment. In fact, in the studies conducted in the literature, it is stated that approaches that will allow students to explain themselves will contribute to the development of reasoning skills (Kramarski \& Zoldan, 2008; MoNE, 20018a; NCTM, 1989).

According to the findings obtained from the opinions of the participants regarding the learning environment, it is understood that this learning environment increases the participation of the students in the lesson. It can be concluded that the increase in participation indicates that students have a positive attitude towards the lessons and the problems solved in this learning environment. In addition, this learning environment provided both effective and permanent learning, and promoted the use of reasoning skills. In this case, it can be said that students acquired sufficient knowledge level of concept and method. In summary, it can be interpreted that students' mathematical reasoning skills were improved because they gained positive attitude and acquired sufficient concept and method knowledge. In fact, Erdem (2015) states that in order for the students to create and develop a mathematical reasoning culture, it is necessary to provide positive attitudes and provide sufficient concept and method knowledge. There are some research studies in the literature that achieve results in parallel with the findings obtained in the current study that the learning environment enriched with various methods improves mathematical reasoning skills. As a matter of fact, many cases are mentioned in the literature in order to improve mathematical reasoning skills.

According to the findings of this study, which aims to evaluate the learning process enriched with various teaching methods, which require multiple senses to appeal to students' learning preferences, in the context of mathematical reasoning skills from the perspectives of the participant teacher and students; it was determined that the students had a positive attitude towards the lessons by increasing their participation in the lesson. Besides, it was determined that the teaching approach adopted in the current research provides effective and permanent learning and increases the use of reasoning. As a result of this teaching, it was found that the participant students have reached sufficient concept and method knowledge. Moreover, it is understood that at the end of this research, participant students have a mathematical culture of reasoning, and their mathematical reasoning skills develop. Based on these results, some suggestions are presented below: Teachers can implement mathematics lessons more efficiently by using various teaching methods. In this regard, in-service training courses can be organized in cooperation with education faculties to design teaching materials that can be utilized in the courses. In the context of learning styles, the effect of enriched learning environment can be examined by creating equivalent experimental groups. 


\section{References}

Algani, Y. M., \& Eshan, J. (2019). Reasons and suggested solutions for low-level academic achievement in mathematics. International e-Journal of Educational Studies (IEJES), 3(6), 181-190. doi: 10.31458/iejes.604884

Çetin, Y., \& Mirasyedioğlu, Ş. (2019). Teknoloji destekli probleme dayalı öğretim uygulamalarının matematik başarısına etkisi [The effects of the technology supported problem-based learning activities on students' achievement in mathematics]. Journal of Computer and Education Research, 7(13), 13-34. doi: 10.18009/jcer.494907

Dovis, S., Van der Oord, S., Wiers, R. W., \& Prins, P. J. (2013). What part of working memory is not working in ADHD? Short-term memory, the central executive and effects of reinforcement. Journal of Abnormal Child Psychology, 41(6), 901-917.

Erdem, E., Fırat, T., \& Gürbüz, R. (2019). Improving mathematical reasoning and mathematics attitude of disadvantaged children in rural regions. Journal of Computer and Education Research, 7(14), 673-697. doi: 10.18009/jcer.628742

Erdem, E. (2015). Zenginleştirilmiş öğrenme ortamının matematiksel muhakeme ve tutuma etkisi [The effect of enriched learning environment on mathematical reasoning and attitude]. (Unpublished doctoral thesis). Atatürk University, Erzurum.

Erdem, E., Gürbüz, R., \& Duran, H. (2011). An investigation of mathematics used in daily life from past to present: Theory out practice in. Turkish Journal of Computer and Mathematics Education, 2(3), 232-246.

Ertem-Akbaş, E. (2019). Eğitim bilişim ağı (EBA) destekli matematik öğretiminin 5. sınıf kesir konusunda öğrenci başarılarına etkisi [The impact of EIN (educational informatics network) assisted mathematics teaching in $5^{\text {th }}$ grade fractions on students' achievements]. Journal of Computer and Education Research, 7(13), 120-145. doi: $10.18009 / 531953$

Gencel, İ. E. (2007). Kolb’ün deneyimsel öğrenme kuramına dayalı öğrenme stilleri envanteri-III'ü Türkçeye uyarlama çalışması [Inventory of learning styles based on the experiential learning theory of Kolb - a study of adapting III to Turkish]. Dokuz Eylul University Journal of Social Sciences Institute, 9(2), 120-139.

Gök, M. (2020). Sinıf öğretmeni adaylarının bir mobil oyun deneyimi: aritmetiğin temel teoremi [A mobile game experience of pre-service elementary teachers: The fundamental theorem of arithmetic]. Journal of Computer and Education Research, 8(15), 41-74. doi: 10.18009/jcer.643732

Heasly, B., Lindner, J., Iliško, Dz., \& Salìte, I. (2020). From initiatives, to insights, to implementation of the sustainability and securitability Agenda for 2030. Discourse and Communication for Sustainable Education, 11(1), 1-4.

Jeffrey, B., \& Craft, A. (2004). Teaching creatively and teaching for creativity: Distinctions and relationships. Educational Studies, 30(1), 77-87.

Kasmer, L., \& Kim, O. K. (2011). Using prediction to promote mathematical understanding and reasoning. School Science and Mathematics, 111(1), 20-33.

Kolb, A. Y., \& Kolb, D. A. (2005). The Kolb learning style inventory-Version 3.1: 2005 technical specifications. Boston, MA: Hay Resources Direct.

Kolb, D. A. (2005). Learning style inventory-version 3.1. Boston: Hay Group.

Kramarski, B., \& Zeichner, O. (2001). Using technology to enhance mathematical reasoning: Effects of feedback and self-regulation learning. Educational Media International, 38(2-3), 77-82. 
Kramarski, B., \& Zoldan, S. (2008). Using errors as springboards for enhancing mathematical reasoning with three metacognitive approaches. The Journal of Educational Research, 102(2), 137-151.

Kramarski, B., Mevarech, Z. R., \& Lieberman A. (2001). Effects of multilevel versus unilevel metacognitive training on mathematical reasoning. Journal of Educational Research, 94(5), 292-300.

Kükey, E., Aslaner, R., \& Tutak, T. (2019). Matematiksel düşünmenin varsayımda bulunma bileşeni kapsaminda ortaokul öğrencilerinin kullandıkları problem çözme stratejilerinin incelenmesi [An investigation of the problem solving strategies used of middle school students for of the assumption component of mathematical thinking]. Journal of Computer and Education Research, 7(13), 146-170.

Merriam, S. M. (2009). Qualitative research: A guide to design and implementation. San Fransisco, CA: John Wiley \& Sons Inc.

Miles, M. B., \& Huberman, A. M. (1994). An expanded sourcebook: Qualitative data analysis (2nd ed.). Thousand Oaks, CA: SAGE.

Ministry of National Education [MoNE]. (2015). Ortaokul matematik dersi (5, 6, 7 ve 8. simıflar) ögretim programı [Secondary school mathematics lesson (grades 5-8) curriculum]. Ankara: TTKB.

Ministry of National Education [MoNE]. (2018a). Matematik dersi öğretim programı (İlkokul ve ortaokul 1, 2, 3, 4, 5, 6, 7 ve 8. Siniflar) [Mathematics curriculum (primary and secondary school grades 1-8)]. Ankara: TTKB.

Ministry of National Education [MoNE]. (2018b). 2018 Liselere geçiş sistemi (LGS): Merkezi sınavla yerleşen öğrencilerin performansı. Ĕ̆itim analiz değerlendirme raporlarn serisi [2018 high school transition system (LGS): Performance of students settled by central exam. Education analysis evaluation reports series]. Ankara.

Naksutthi, K., \& Chidmongkol, S. (2017). Effect of organizing mathematics learning activities using proof mapping technique to write geometric proofs on geometric reasoning ability of eighth grade students. An Online Journal of Education, 12(2), 18-31.

National Council of Teachers of Mathematics [NCTM]. (1989). Curriculum and evaluation standards for school mathematics. Reston: Virginia.

Novak, J. D., \& Gowin, D. B. (1984). Learning how to learn. New York: Cambridge University.

Ok, G. (2020). The impact of the contents of educational informatics network on classroom participation of students in teaching the subject of the musculoskeletal system. Journal of Computer and Education Research, 8(15), 224-240. doi: 10.18009/ jcer.684362

Özgen, K., \& Alkan, H. (2014). The effects of learning activities corresponding with students' learning styles on academic success and attitude within the scope of constructivist learning approach: The case of the concepts of function and derivative. Turkish Journal of Computer and Mathematics Education, 5(1), 1-38. doi: 10.16949/ turcomat.35299

Pape, S. J., Bell. C. V., \& Yetkin, I. E. (2003). Developing mathematical thinking and self-regulated learning: A teaching experiment in a seventh-grade mathematics classroom. Educational Studies in Mathematics, 53, 179-202. 
Pijls, M., Dekker, R., \& Van Hout-Wolters, B. (2007). Reconstruction of a collaborative mathematical learning process. Educational Studies in Mathematics, 65, 309-329. doi: 10.1007/s10649-006-9051-3

Polaki, M. V. (2002). Using instruction to identify key features of Basotho elementary students' growth in probabilistic thinking. Mathematical Thinking and Learning, 4(4), 285-313.

Salite, I. (2008). Educational action research for sustainability: Constructing a vision for the future in teacher education. Journal of Teacher Education for Sustainability, $10,5-16$.

Salìte, I., Fjodorova, I., Meihami, H., Ivanova, I., Iliško, Dz., \& Gholami, J. (2020). JTES approaches to sustainability: Current practices and new perspectives for a more sustainable world. Journal of Teacher Education for Sustainability, 21(2), 1-4.

Topuz, F., \& Birgin, O. (2020). Yedinci sınıf “çember ve daire” konusunda geliştirilen geogebra destekli öğretim materyaline ve öğrenme ortamına ilişkin öğrenci görüşleri [Students' views about geogebra-supported teaching material and learning environment developed for "circle and disc" subject at the $7^{\text {th }}$ grade]. Journal of Computer and Education Research, 8(15), 1-27. doi: 10.18009/jcer.638142

Tum, A., \& Kutluca, T. (2019). Matematiksel muhakeme bağlamında tam sayılar ve kesirler konularına yönelik zenginleştirilmiş öğrenme etkinlikleri [Enriched learning activities for integers and fractions in the context of mathematical reasoning]. In Proceedings Book $8^{\text {th }}$ Eurasian Conference on Language and Social Sciences (p. 4770), October 18-20, Antalya, Turkey. doi: 10.35578/eclss.52775

Yıldırım, A., \& Şimşek, H. (2016). Sosyal bilimlerde nitel araştirma yöntemleri (10. Bask1) [Qualitative research methods in the social sciences]. Ankara: Seçkin Yayıncilık.

Correspondence relating this article should be addressed to Tamer Kutluca, Dicle University, Turkey.Email: tkutluca@dicle.edu.tr 